\title{
Bacillus thuringiensis as microbial biopesticide: uses and application for sustainable agriculture
}

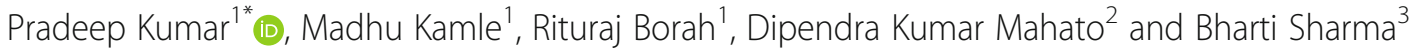

\begin{abstract}
Background: Bacillus thuringiensis (Bt) has been used in agriculture for a long time because of its insecticidal proteins which make it a valuable environment-friendly biopesticide. However, its use is not only limited to insecticidal properties. Current and previous studies indicate its potential as a biofertilizer for promoting plant growth, the development of transgenic plants, and others. It is the presence of $\delta$-endotoxins, especially cry protein, which attributes the insecticidal property to the bacteria. Besides, there are some vegetative and secreted insecticidal proteins that exert their toxic activity towards specific species.

Main body of abstract: The present review briefly provides an overview of the Bt uses and application as a biocontrol agent against insect pest for sustainable agriculture. Historical development of Bt as biocontrol, classification of various cry proteins, their mechanisms of actions against different insect-pest, and incorporation of cry genes in the plant for developing transgenic Bt plants such as Bt cotton, potato, and maize. Applications of Bt as biofertilizer and the various bioformulations as biopesticide are also described.

Short conclusion: Uses of harmful pesticides and chemical cause various health issues and environmental problem; therefore, the Bt served as the best alternative to overcome the above issue. Also, we aim to explore the potential as plant growth-promoting potential and solubilization of minerals and the uses as a biofertilizer, keeping the high specificity and environmental safety of Bt. Its various formulations are commercially available and considered an efficient alternative to chemical pesticides.
\end{abstract}

Keywords: Bacillus thuringiensis, Biopesticide, Biofertilizer, Environment, Human health

\section{Background}

Bacillus thuringiensis $(B t)$ is a gram-positive, sporeforming bacteria known for its ability to produce crystal proteins (Cry). Cry protein is believed to be toxic to many insects and that is why $B t$ is used as a microbial insecticide for improved resistance in plants by genetic modification (Salehi Jouzani et al. 2008). When the insect larvae ingest the proteinaceous crystal, the digestive enzymes present in the gut activates the toxin and

\footnotetext{
* Correspondence: pkbiotech@gmail.com

${ }^{1}$ Applied Microbiology Laboratory, Department of Forestry, North Eastern Regional Institute of Science and Technology, Nirjuli, Arunachal Pradesh 791109, India

Full list of author information is available at the end of the article
}

results in pore formation in the cell membrane of the gut, followed by paralysis of the gut and eventually causing the death of the larvae (Vachon et al. 2012). Cry proteins target a diverse range of insect species primarily of the order Lepidoptera (butterflies and moths), Coleoptera (beetles and weevils), and Diptera (flies and mosquitoes); however, there are reports regarding their toxicity towards hymenopterans (wasps and bees) and nematodes (Domínguez-Arrizabalaga et al. 2020) (Fig. 1). The use of $B t$ as biopesticide are efficient like chemical pesticides, therefore, forms a part of the Integrated Pest Management strategy that prefers non-chemical pesticides for pest control (Matyjaszczyk 2018).

\section{Springer Open}

(c) The Author(s). 2021 Open Access This article is licensed under a Creative Commons Attribution 4.0 International License, which permits use, sharing, adaptation, distribution and reproduction in any medium or format, as long as you give appropriate credit to the original author(s) and the source, provide a link to the Creative Commons licence, and indicate if changes were made. The images or other third party material in this article are included in the article's Creative Commons licence, unless indicated otherwise in a credit line to the material. If material is not included in the article's Creative Commons licence and your intended use is not permitted by statutory regulation or exceeds the permitted use, you will need to obtain permission directly from the copyright holder. To view a copy of this licence, visit http://creativecommons.org/licenses/by/4.0/. 


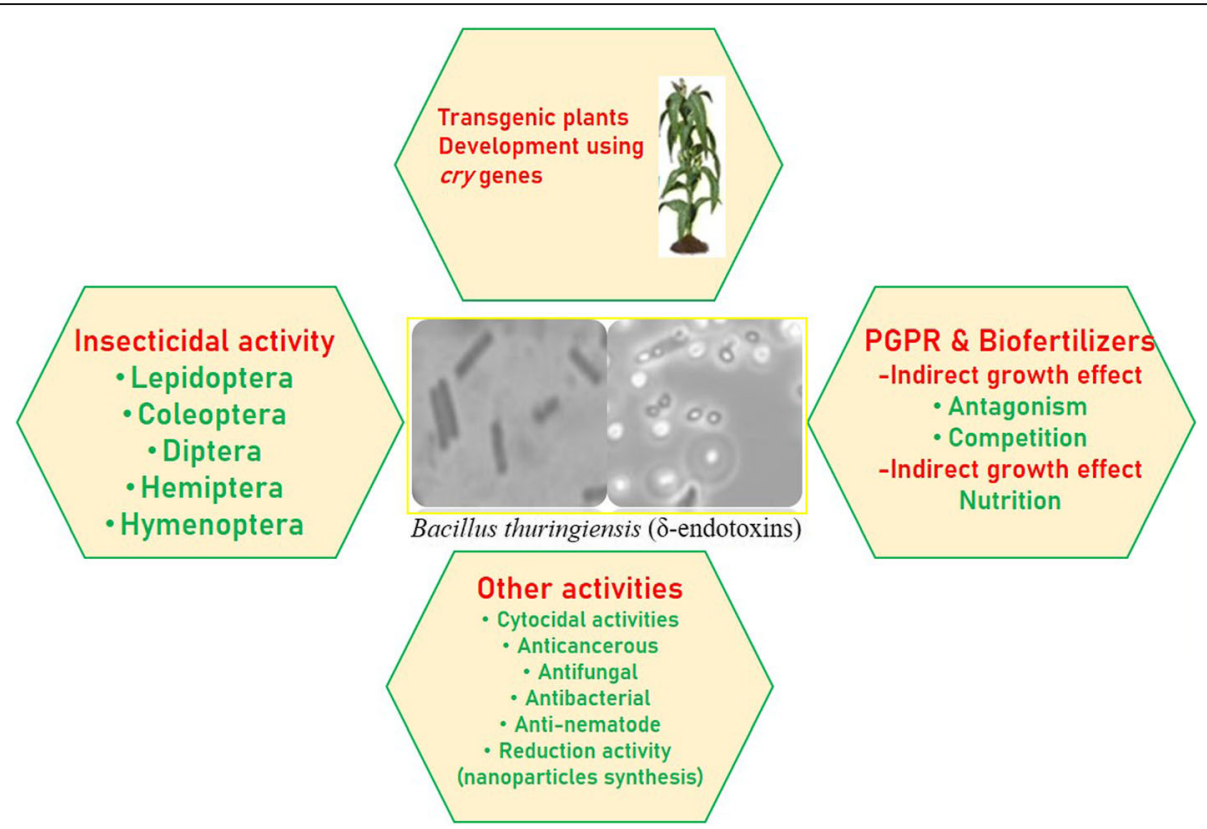

Fig. 1 Applications of Bacillus thuringiensis for sustainable agriculture

Besides the crystal proteins, $B t$ also synthesizes vegetative insecticidal protein (Vip) and secreted insecticidal protein (Sip), which are biodegradable and affect specific targets, especially species of Coleoptera and Lepidoptera (Chakroun et al. 2016). Since the use of chemical pesticides results in the development of resistance by the insects and is harmful to both humans and the environment, the focus is to develop effective biopesticides using $B t$. The current research focuses on developing genetically engineered crops to express insecticidal property from $B t$ (Bravo et al. 2011). Moreover, it is a host-specific bioinsecticide; hence, there is limited chances of negatively affecting other organisms (Jain et al. 2016). Further, its role as an insecticide has explored its potential in promoting plant growth (Armada et al. 2016), bioremediation of heavy metals (AcevesDiez et al. 2015), and production of polymers (Singh et al. 2013).

\section{Main text}

\section{History}

Bacillus thuringiensis (Bt) was first discovered in 1901 by the Japanese biologist, Shigetane Ishiwatari, before which it was believed that an undescribed bacterium is responsible for causing disease in silkworms (Ishiwata 1901). In 1911, Bt was rediscovered by Ernst Berliner, in Germany, as the causative agent of a disease known as Schlaffsucht in Mediterranean flour moth caterpillars, Ephestia kuehniella Zell. Bt was named after the province Thuringia where the infection was found. Hence, $B t$ was initially considered a risk for silkworm rearing but later it became an insecticidal agent (Berliner 1915; Mazier et al. 1997). The first commercial production of $B t$ was reported in 1938 in France and sold under the name Sporeine (Brar et al. 2006). A study by Angus (1956) demonstrated that the insecticidal action of $B t$ was due to certain crystalline protein inclusions formed during sporulation. Later, a study by Zakharyan et al. (1976) noted the presence and involvement of plasmid in crystal formation in Bt. Then, González et al. (1982) used plasmid curing technique and affirmed the localization of genes that code for crystal proteins on transmissible plasmids. However, the first cloning and characterization of these crystal protein-encoding genes that showed toxicity towards tobacco hornworm larvae were performed by Schnepf and Whiteley (1981) from plasmid DNA of $B t$ subsp. kurstaki HD-1. This resulted in rapid cloning of other cry genes, which ultimately led to the expansion of genetic engineering towards $B t$ transgenic plants and finally, $B t$ cotton reached the market in 1996 (Shelton et al. 2002).

\section{$B t$ toxin-diversity and classification}

Bacillus thuringiensis strains produce 2 types of toxins, cry and cyt proteins, which are also known as deltaendotoxins (Bravo et al. 2007). These are synthesized by the bacteria during its stationary phase when sporulation occurs. They are produced as parasporal crystalline inclusions which get activated by the proteolytic action inside the insect's gut after ingestion. These proteins are not known to be toxic against invertebrates and are called parasporins (PS) (Ohba et al. 2009). Besides this, 
certain toxins are produced during the vegetative phase, termed as vegetative insecticidal proteins (Vip) and secreted insecticidal protein (Sip). The Sip (Sip1Aa1 obtained from $B t$ strain EG2158) is the only known protein to show toxicity against coleopteran larvae. These are secreted by the bacteria in the culture medium (Palma et al. 2014).

The main types are the crystal (Cry) genes which encode intestinal cry protein (ICP) toxins and have a wide spectrum of insecticidal activity. There are more than 800 cry genes classified under 75 families (Cry1 to Cry 75), 40 cyt genes grouped in 3 families (Cyt 1, cyt2, cyt3), and 146 Vip genes categorized under 4 families (Vip 1 to Vip4) (Crickmore et al. 2020). Initially, these toxins were classified into 4 classes based on their amino acid sequence homology and insecticidal properties. The CryI toxins are toxic to Lepidopterans (butterflies and moths), CryII genes are toxic to lepidopterans and dipterans (flies and mosquitoes), CryIII genes are toxic to coleopterans (beetles and weevils), and CryIV genes are toxic to dipterans (Höfte and Whiteley 1989). An additional class, $\mathrm{CryV}$, was added for the nematode-active toxins (Sick et al. 1994). Similarly, secreted toxins show their toxicity to a particular order of insects. Vip1 and Vip2 are binary toxins and toxic to coleopterans and hemipterans (Sattar and Maiti 2011), Vip3, on the other hand, is single-chain and show insecticidal activity towards lepidopterans (Estruch et al. 1996). The nomenclature also determines the similarity in the amino acid sequence between the cry genes on 4 levels for their distinguished. However, this naming method did not consider the biological activity. In this system, each protoxin acquired a name consisting of the mnemonic Cry (cyt, Vip, or Sip) and divided into various ranks. For example, at level 1 , each gene in the family cry1 shares at least $45 \%$ similarity and will be categorized under cry 1 . The secondary rank introduces a capital letter, say, Cry1A, which indicates towards the sequences with the similarity between 45 and $78 \%$. This is followed by tertiary rank, say, Cry1Aa, which increases the sequence identity up to $95 \%$ but not less than $78 \%$. At the fourth level, quaternary rank, say, Cry1Aa2, clones that share at least 95\% sequence identity are distinguished (Crickmore 1998; 2020).

Another method of classification by $B t$ toxin Nomenclature Committee uses the homology approach and forms 3 groups based on phylogenetics-3 domain groups, bin group, and epsilon toxin (ETX) group. The cry toxins belonging to three-domain group differ in their amino acid sequence but share a common threedomain structure. The structure includes a perforating domain, central domain, and galactose-binding domain, each playing a specific role during toxin activation (Pardo-Lopez et al. 2013). The bin group contains toxins derived from Lysinibacillus sphaericus (Cry 35 and Cry36) (Berry 2012) and the ETX group contains toxins that show resemblance to toxins produced by Clostridium epsilon (Alves et al. 2014). Their structure shows fold like aerolysin, a toxin produced by Aeromonas hydrophila and involved in pore formation (Knapp et al. 2010). The second types are the cytolytic (cyt) genes encoding non-specific cytolytic factor toxins that can augment the Cry toxins for enhanced insecticidal property especially against dipterans (Butko 2003). This helps in decreasing the resistance of insects towards cry proteins. For instance, a study by Soberón et al. (2013) observed that Cyt1Aa toxin produced by $B t$ helped in decreasing the resistance developed by the larvae of Culex quinquefasciatus against Cry 4 and Cry11Aa toxin. Moreover, there is evidence indicating a wider range of toxicity (Guerchicoff et al. 2001).

\section{Mechanism of toxicity ( $B t$ as insecticide)}

The most approved and widely accepted primary mode of action of the $B t$ toxin is the lysis of epithelial cells in the midgut of the insect. The toxin acts from the exterior of the cells and enters into the plasma membrane but it does not enter the cytoplasm. The earliest effect shows the blabbing and swelling of columnar cells and subsequent lysis of the columnar cells. The effect seen on goblet cell is slower when compared (Liu et al. 2018). The steps involved in the action in lepidopteran are explained in brief through. On the ingestion of the toxin in lepidopteran in the first $5 \mathrm{~min}$, the glucose uptake is increased in the gut cells and the histopathology takes place in the gut cells (Knowles 1994). After $5 \mathrm{~min}$, the mid-gut gets paralyzed. Within $10 \mathrm{~min}$, the columnar cells get swelled up and the columnar microvilli get bubbled. The histopathology takes place in the goblet cells. Subsequently, the $\mathrm{pH}$ is increased in the blood and decreased in the lumen. Then, within $30 \mathrm{~min}$, the activity of potassium ion is increased in the gut cells which lead to the decrease in the blood potassium ion level. The leucine and the glucose level start to decrease leading the gut cells to metabolically break down. After $30 \mathrm{~min}$, the cells undergo lysis and start to shed from the basement membrane. Within 1 to $7 \mathrm{~h}$, general paralysis takes place. After 1 to 3 days, it dies to starvation (Liu et al. 2018). Different types of insecticidal proteins are produced by Bt. About 950 different types of toxins are cloned from about 74 groups of cry, 3 groups of vip, and 3 groups of cyt protein (Crickmore et al. 2020).

$\mathrm{Li}$ et al. (2011) studied the toxicity behavior of Cry1Ac and Cry3Aa against the pea aphid, Acyrthosiphon pisum (Harris). Cry1Ac was observed to be efficiently hydrolyzed by aphid stomach membrane-associated cysteine proteases $(\mathrm{CP})$ whereas Cry3Aa was processed incompletely and degraded partially. Cry1Ac could bind to the 
aphid gut epithelium but bioassays showed low aphid toxicity. In addition, the competition assays using unlabelled Cry1Ac and GalNAc and in vitro binding of biotinylated-Cry1Ac to gut BBMVs (brush border membrane vesicles) confirmed binding specificity besides glycan mediation of Cry1Ac binding. Further, Zhang et al. (2019) revealed Vip3Aa11 and Vip3Aa39 proteins presenting 39 amino acid differential sites, sharing $95.06 \%$ amino acid sequence similarity and effective against some Lepidoptera insect larvae. They also revealed 558 midgut genes expressed differentially in Vip3Aa11-M-A and 65 midgut genes expressed differentially in Vip3Aa39-M-A. The validation for the sensitivity of these two Vip3Aa proteins to trypsin and their binding properties to Agrotis ipsilon midgut BBMV based on transcriptome profiling showed similar sensitivity to trypsin and both proteins could bind to Agrotis ipsilon midgut BBMV along with competitive binding between them (Zhang et al. 2019).

\section{Bt and genetically modified plants}

The recent advancements in modern biotechnology especially in the field of agriculture are observed globally. The global average of the biotech crops has reached 191.7 million hectares in the last 22 years (ISAAA 2019). These are the fastest adapted crops that have now reached to 70 countries after commercialization (Pocket 2018). Traits of $B t$ such as pest resistant and herbicide are most extensively used in plant genetic engineering. Bt toxin genes are widely used in many crops for enhancing pest-resistant quality (Jouzani et al. 2017). Since the commercialization of Bt crops, approximately 198 varieties have been produced lining up 8 plants including potato, soybean, corn, maize, eggplant, cotton, rice, poplar, tomato, and maize. Recently, maize has gained the largest number of approvals (137) from over 35 countries (ISAAA 2016). During sporulation, $B t$ forms aggregated crystals that are cry toxins, which is an insecticidal protein with a parasporal body and crystalline structure. These toxins are effective on specific species like Nematoda, Lepidoptera, Coleoptera, Diptera, and Hymenoptera (Abbas 2018). Genetically modified (GM) crops consist of one or more than one vip or cry genes. Cotton, corn, and potato have 42,115 , and 30 variants, respectively, and they are the most extensively approved Bt-GM crop (ISAAA 2016). There are in total seven anti-lepidopteran vip and cry genes used for enhancing the resistance to Lepidopteran genes namely cry1A.105, cry1Ab, cry1F, cry1Ac, cry2Ae, cry2Ab, and vip3A. About $111 B t$ varieties of anti-coleopteran genes are approved, among which some are anti-lepidopteran pests. Two genes namely cry34Ab1-cry35Ab1 and cry3A are used in nearly 34 and 60 GM crops, respectively, to produce varieties that are resistant to coleopteran pests (Jouzani et al. 2017).
Further, Muddanuru et al. (2019) developed transgenic castor (Ricinus communis L.) expressing the Cry1Aa of Bt against lepidopteran insect pests. Bt toxins of the Cry1I class show dual specificity for insects of Coleoptera and Lepidoptera. Berretta et al. (2020) evaluated the toxicity of a Crylla protein from an Argentinian Bt strain against agricultural pests of Tenebrionidae, Curculionidae, Noctuidae, and Tortricidae. The protein was toxic to Cydia pomonella, and Rachiplusia nu; however, Alphitobius diaperinus, Anthonomus grandis, and Spodoptera frugiperda were not susceptible. Besides this, Singh et al. (2021) revealed the potential of Cry protein isolated from $B t$ to hamper the growth of S. litura, G. malonella, B. cucurbitae, and C. pipens larvae, thereby, the potential for plant breeders to produce resistant crops.

In recent years, it has been seen that the cry genes with resistant properties against nematodes and other insects have not been approved at the commercial level. Along with the advantages of GM crops, there lie potential risks to both human and animal health. It is assumed that consumption of GM crops can cause the potential development of diseases that are resistant to antibodies. Although, any kind of threat or long-term effect has not been reported (Bawa and Anilakumar 2013). Also, the insecticidal proteins of $B t$ are utilized for formulations of spore-crystal complexes along with their genes for producing several GM crops. Despite the variability of the Cry proteins, it is still crucial to search for toxins with a broad-spectrum application so that alternatives are available to address the issues of insect resistance (Lazarte et al. 2021).

\section{$B t$ as a biofertilizer}

There are several bacterial species such as Klebsiella, Pseudomonas, Rhizobium, Caulobacter, and Azotobacter are known for enhancing plant growth (Kumar et al. 2016). Bt, although known for its insecticidal activity, is also a plant growth-promoting bacterium. The indirect effect can be observed as it decreases the infection by insects but certain studies indicate towards its direct effect by colonization in legumes which result in an increase in nodulation and thus growth of the plant (Qi et al. 2016).

A study by Seshadri et al. (2007) showed that species of Bacillus (Bt and B. sphaericus) can solubilize phosphates and thereby supporting plant growth. This is beneficial since the mineral is present in a high amount in soil, but its uptake is limited because of its undissolved form. Similarly, dissolution of iron is also difficult, and plant uses the siderophore-iron complex for its uptake. Siderophores are produced by microorganisms and bind with iron and aid in their uptake. A study by Wilson et al. (2006) indicated the production of catecholatetype siderophores by Bt strain ATCC 33679, which 
bound with high affinity to iron and improved its supply to plants. Improved growth in plants has been shown in a study by Mishra et al. (2009) where they investigated that Bacillus thuringiensis-KR1 along with Bradyrhizobium japonicum increased the number of root nodules, improved root volume, root weight, and shoot weight in soybean.

Another study by Mishra et al. (2009) showed that coinoculation of $B t$ with another bacteria Rhizobium leguminosarum in pea plants enhanced the nodulation and increased the dry weight of pea. The colonization of $B t$ is not only observed in lentils but is also reported by Pindi et al. (2014) which showed enhanced growth in cabbage and cotton respectively. Similarly, when coinoculated with mycorrhiza, Armada et al. (2016) reported an improvement in drought tolerance and an increase in oxidative metabolism in plants of Lavandula. A recent study by Bandopadhyay (2020) involved the use of $B t$ A5-BRSC as a charcoal-based biofertilizer for 2 years on Abelmoschus esculentus and evaluated its potential in improving plant growth considering both nutritional and morphological characteristics of the plant. He observed a significant increase in shoot height, leaf diameter, weight of both fruit and seed, and length of roots. Along with this, nearly about $70 \%$ increase in protein content of leaf, more than $60 \%$ increase in soluble sugar content, and about 30\% increase in protein content of the pod were observed with the use of $B t$ as a biofertilizer. These evident studies thus prove that using $B t$ is not only helpful as an insecticide but also has potential as a biofertilizer that is also beneficial for the growth of the plant.

\section{Bt formulations}

Though $B t$ serves as an excellent biopesticide, it faces some problem during storage and stability. The formulation will not only stabilize the biopesticide, but it will also solve some other problems such as application and handling of the product, protect from environmental effects, and enhance activities of agents like microbes in the field (Derua et al. 2018). The most important objective is the widespread and commercialization of these biopesticides globally. The present day's formulation has additional benefits of speed killing, dry and wet (moisture), wind, rains, and characteristics of plants such as the chemistry of leaves (Brar et al. 2006).

\section{Conclusion}

Bacillus thuringiensis $(B t)$ is used as a potential biopesticide to control pests in agriculture due to its various insecticidal proteins. Thereby, the insecticidal toxins derived from $B t$ make it a novel organism with immense potential for agricultural development. With the advancement in technology, its genetic content is now being engineered for the development of Bt-GM crops, which are resistant to pests and insects but without harmful effects on humans, the environment, and beneficial organisms. The use of $B t$ formulations in form of sprays or liquid suspensions on a commercial scale is increasing. Since the toxin is produced continuously for a longer time, it is comparatively better than chemical pesticides in terms of application and field management as well as cost and efficiency. Further research is underway for exploring other useful benefits of $B t$. Besides, being used as a microbial pesticide, $B t$ has also been used as a plant growth-promoting bacterium for enhancing the productivity of crops. However, more focused and indepth research is still required to ensure its effectiveness and long-term effects on the crops, environment, and human health. In addition, studies at the cellular and molecular levels using animal models are vital to fully understand its mode of action for usage as medicine. Additionally, advanced research on the stability, quantity, and crop-specific application dosages are equally essential to ensure the safety of sustainable agriculture.

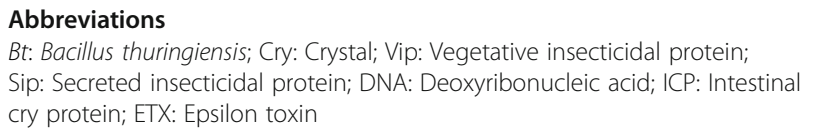

\section{Acknowledgements}

All authors are highly grateful to the authority of the respective department and Institution for their support in conducting this research. Author (P.K.) would like to thank the DST-SERB (ECR/2017/001143) for their financial support

\section{Authors' contributions}

P.K. conceived and designed the manuscript. M.K., D.K.M., B.S., and P.K. wrote the manuscript. R.B. helped in revision. P.K. critically reviewed the manuscript and did the required editing. All authors have read and approved the manuscript.

\section{Funding}

Author, P.K., would like to thank the Early Career Research Award, DST-SERB, Government of India (file no. ECR/2017/001143), for their financial support to carry out this research work.

Availability of data and materials

Not applicable.

\section{Declarations}

Ethics approval and consent to participate

Not applicable.

Consent for publication

Not applicable.

\section{Competing interests}

The authors declare that they have no competing interests.

\section{Author details}

'Applied Microbiology Laboratory, Department of Forestry, North Eastern Regional Institute of Science and Technology, Nirjuli, Arunachal Pradesh 791109, India. ${ }^{2}$ CASS Food Research Centre, School of Exercise and Nutrition Sciences, Deakin University, Burwood, VIC 3125, Australia. ${ }^{3}$ Department of Dairy Science and Food Technology, Institute of Agricultural Sciences, Banaras Hindu University, Varanasi 221005, India. 
Received: 26 March 2021 Accepted: 10 June 2021

Published online: 19 June 2021

\section{References}

Abbas MST (2018) Genetically engineered (modified) crops (Bacillus thuringiensis crops) and the world controversy on their safety. Egypt J Biol Pest Control 28(1):1-12

Aceves-Diez AE, Estrada-Castañeda KJ, Castañeda-Sandoval LM (2015) Use of Bacillus thuringiensis supernatant from a fermentation process to improve bioremediation of chlorpyrifos in contaminated soils. J Environ Manag 157: 213-219. https://doi.org/10.1016/j.jenvman.2015.04.026

Alves GG, de Ávila RAM, Chávez-Olórtegui CD, Lobato FCF (2014) Clostridium perfringens epsilon toxin: the third most potent bacterial toxin known. Anaerobe 30:102-107. https://doi.org/10.1016/j.anaerobe.2014.08.016

Angus TA (1956) Association of toxicity with protein-crystalline inclusions of Bacillus sotto Ishiwata. Can J Microbiol 2(2):122-131. https://doi.org/10.1139/ m56-017

Armada E, Probanza A, Roldán A, Azcón R (2016) Native plant growth promoting bacteria Bacillus thuringiensis and mixed or individual mycorrhizal species improved drought tolerance and oxidative metabolism in Lavandula dentata plants. J Plant Physiol 192:1-12. https://doi.org/10.1016/j.jplph.2015.11.007

Bandopadhyay S (2020) Application of plant growth promoting Bacillus thuringiensis as biofertilizer on Abelmoschus esculentus plants under field condition. J Pure Appl Microbiol 14(2):1287-1294. https://doi.org/10.22207/ JPAM.14.2.24

Bawa AS, Anilakumar KR (2013) Genetically modified foods: safety, risks and public concerns - a review. J Food Sci Technol 50(6):1035-1046. https://doi. org/10.1007/s13197-012-0899-1

Berliner E (1915) Über die Schlaffsucht der Mehlmottenraupe (Ephestia kühniella Zell.) und ihren Erreger Bacillus thuringiensis n. sp. Z Angew Entomol 2(1):2956

Berretta MF, Pedarros AS, Sauka DH, Pérez MP, Onco MI, Benintende GB (2020) Susceptibility of agricultural pests of regional importance in South America to a Bacillus thuringiensis Cry1la protein. J Invertebr Pathol 172:107354. https://doi.org/10.1016/j.jip.2020.107354

Berry C (2012) The bacterium, Lysinibacillus sphaericus, as an insect pathogen. J Invertebr Pathol 109(1):1-10. https://doi.org/10.1016/j.jip.2011.11.008

Brar SK, Verma M, Tyagi RD, Valéro JR (2006) Recent advances in downstream processing and formulations of Bacillus thuringiensis based biopesticides. Process Biochem 41(2):323-342. https://doi.org/10.1016/j.procbio.2005.07.015

Bravo A, Gill SS, Soberon M (2007) Mode of action of Bacillus thuringiensis Cry and Cyt toxins and their potential for insect control. Toxicon 49(4):423-435. https://doi.org/10.1016/j.toxicon.2006.11.022

Bravo A, Likitvivatanavong S, Gill SS, Soberón M (2011) Bacillus thuringiensis: a story of a successful bioinsecticide. Insect Biochem Mol Biol 41(7):423-431. https://doi.org/10.1016/j.ibmb.2011.02.006

Butko P (2003) Cytolytic toxin Cyt1A and its mechanism of membrane damage: data and hypotheses. Appl Environ Microbiol 69(5):2415-2422. https://doi. org/10.1128/AEM.69.5.2415-2422.2003

Chakroun M, Banyuls N, Bel Y, Escriche B, Ferré J (2016) Bacterial vegetative insecticidal proteins (Vip) from entomopathogenic bacteria. Microbiol Mol Biol Rev 80(2):329-350. https://doi.org/10.1128/MMBR.00060-15

Crickmore N, Berry C, Panneerselvam S, Mishra R, Connor TR, Bonning BC (2020) A structure-based nomenclature for Bacillus thuringiensis and other bacteriaderived pesticidal proteins. J Invertebr Pathol:107438. https://doi.org/10.1016/ j.jip.2020.107438

Crickmore N, Zeigler DR, Feitelson J, Schnepf E, Van Rie J, Lereclus D, Baum J, Dean DH (1998) Revision of the nomenclature for the Bacillus thuringiensis pesticidal crystal proteins. Microbiol Mol Biol Rev. 62(3):807-13. https://doi. org/10.1128/MMBR.62.3.807-813.1998

Crickmore N, Berry C, Panneerselvam S, Mishra R, Connor TR, Bonning BC (2020) A structure-based nomenclature for Bacillus thuringiensis and other bacteriaderived pesticidal proteins. J Invertebr Pathol. 2020:107438. https://doi.org/1 0.1016/j.jip.2020.107438

Derua YA, Kahindi SC, Mosha FW, Kweka EJ, Atieli HE, Wang X, Zhou G, Lee MC, Githeko AK, Yan G (2018) Microbial larvicides for mosquito control: Impact of long lasting formulations of Bacillus thuringiensis var israelensis and Bacillus sphaericus on non-target organisms in western Kenya highlands. Ecol Evol 8(15):7563-7573. https://doi.org/10.1002/ ece 3.4250
Domínguez-Arrizabalaga M, Villanueva M, Escriche B, Ancín-Azpilicueta C, Caballero P (2020) Insecticidal activity of Bacillus thuringiensis proteins against Coleopteran pests. Toxins 12(7):430. https://doi.org/10.3390/toxins12070430

Estruch JJ, Warren GW, Mullins MA, Nye GJ, Craig JA, Koziel MG (1996) Vip3A, a novel Bacillus thuringiensis vegetative insecticidal protein with a wide spectrum of activities against lepidopteran insects. Proc Natl Acad Sci 93(11): 5389-5394. https://doi.org/10.1073/pnas.93.11.5389

González JM, Brown BJ, Carlton BC (1982) Transfer of Bacillus thuringiensis plasmids coding for delta-endotoxin among strains of $B$. thuringiensis and $B$. cereus. Proc Natl Acad Sci 79(22):6951-6955. https://doi.org/10.1073/pnas. 79.22.6951

Guerchicoff A, Delécluse A, Rubinstein CP (2001) The Bacillus thuringiensis cyt genes for hemolytic endotoxins constitute a gene family. Appl Environ Microbiol 67(3):1090-1096. https://doi.org/10.1128/AEM.67.3.1090-1096.2001

Höfte H, Whiteley HR (1989) Insecticidal crystal proteins of Bacillus thuringiensis. Microbiol Mol Biol Rev 53(2):242-255

ISAAA (2016) International service for the acquisition of agribiotech applications. GM Approval Database https://www.isaaa.org/gmapprovaldatabase/

ISAAA (2019) International service for the acquisition of agribiotech applications. GM Approval Database https://www.isaaa.org/resources/publications/briefs/ 55/executivesummary/default.asp [access on 16.05.2021

Ishiwata S (1901) On a new type of severe flacherie (sotto disease) (original in Japanese). Dainihon Sansi Kaiho 114:1-5

Jain D, Saharan V, Pareek S (2016) Current status of bacillus thuringiensis: insecticidal crystal proteins and transgenic crops. In: Advances in Plant Breeding Strategies: Agronomic, Abiotic and Biotic Stress Traits. Springer, pp 657-698. https://doi.org/10.1007/978-3-319-22518-0_18

Jouzani GS, Valijanian E, Sharafi R (2017) Bacillus thuringiensis: a successful insecticide with new environmental features and tidings. Appl Microbiol Biotechnol 101(7):2691-2711. https://doi.org/10.1007/s00253-017-8175-y

Knapp O, Stiles B, Popoff MR (2010) The aerolysin-like toxin family of cytolytic, pore-forming toxins. Open Toxinol J 3(1):53-68. https://doi.org/10.2174/1 875414701003020053

Knowles BH (1994) Mechanism of action of Bacillus thuringiensis insecticidal $\delta$ endotoxins. Adv In Insect Phys 24:275-308. https://doi.org/10.1016/S0065-2 806(08)60085-5

Kumar A, Singh M, Singh PP, Singh SK, Singh PK, Pandey KD (2016) Isolation of plant growth promoting rhizobacteria and their impact on growth and curcumin content in Curcuma longa L. Biocatal Agric Biotechnol 8:1-7. https://doi.org/10.1016/j.bcab.2016.07.002

Lazarte JN, Valacco MP, Moreno S, Salerno GL, Berón CM (2021) Molecular characterization of a Bacillus thuringiensis strain from Argentina, toxic against Lepidoptera and Coleoptera, based on its whole-genome and Cry protein analysis. J Invertebr Pathol:107563. https://doi.org/10.1016/j.jip.2021.107563

$\mathrm{Li} \mathrm{H}$, Chougule NP, Bonning BC (2011) Interaction of the Bacillus thuringiensis delta endotoxins Cry1Ac and Cry3Aa with the gut of the pea aphid, Acyrthosiphon pisum (Harris). J Invertebr Pathol 107(1):69-78. https://doi.org/10.1016/j.jip.2011.02.001

Liu L, Chen Z, Yang Y, Xiao Y, Liu C, Ma Y, Soberón M, Bravo A, Yang Y, Liu K (2018) A single amino acid polymorphism in ABCC2 loop 1 is responsible for differential toxicity of Bacillus thuringiensis Cry1Ac toxin in different Spodoptera (Noctuidae) species. Insect Biochem Mol Biol 100:59-65. https:// doi.org/10.1016/j.ibmb.2018.06.004

Mazier M, Pannetier C, Tourneur J, Jouanin L, Giband M (1997) The expression of Bacillus thuringiensis toxin genes in plant cells. In: Biotechnology Annual Review, vol 3. Elsevier, pp 313-347

Matyjaszczyk E (2018) "Biorationals" in integrated pest management strategies. J Plant Dis Prot 125:523-527. https://doi.org/10.1007/s41348-018-0180-6

Mishra PK, Mishra S, Selvakumar G, Bisht JK, Kundu S, Gupta HS (2009) Coinoculation of Bacillus thuringeinsis-KR1 with Rhizobium leguminosarum enhances plant growth and nodulation of pea (Pisum sativum L.) and lentil (Lens culinaris L.). World J Microbiol Biotechnol 25(5):753-761. https://doi. org/10.1007/s11274-009-9963-z

Muddanuru T, Polumetla AK, Maddukuri L, Mulpuri S (2019) Development and evaluation of transgenic castor (Ricinus communis L.) expressing the insecticidal protein Cry1Aa of Bacillus thuringiensis against lepidopteran insect pests. Crop Protect 119:113-125

Ohba M, Mizuki E, Uemori A (2009) Parasporin, a new anticancer protein group from Bacillus thuringiensis. Anticancer Res 29(1):427-433

Palma L, Muñoz D, Berry C, Murillo J, Caballero P (2014) Bacillus thuringiensis toxins: an overview of their biocidal activity. Toxins 6(12):3296-3325. https:// doi.org/10.3390/toxins6123296 
Pardo-Lopez L, Soberon M, Bravo A (2013) Bacillus thuringiensis insecticidal three-domain Cry toxins: mode of action, insect resistance and consequences for crop protection. FEMS Microbiol Rev 37(1):3-22. https://doi.org/10.1111/j.1574-6976.2012.00341.x

Pindi PK, Sultana T, Vootla PK (2014) Plant growth regulation of Bt-cotton through Bacillus species. 3 Biotech 4(3):305-315

Pocket K (2018) No. 16: Biotech Crop Highlights in 2018. https://www.isaaa.org/ resources/publications/pocketk/16.

Qi J, Aiuchi D, Tani M, S-i A, Koike M (2016) Potential of entomopathogenic Bacillus thuringiensis as plant growth promoting rhizobacteria and biological control agents for tomato Fusarium wilt. Int J Environ Agric Res 2(6):55-63

Salehi Jouzani G, Seifinejad A, Saeedizadeh A, Nazarian A, Yousefloo M, Soheilivand S, Mousivand M, Jahangiri R, Yazdani M, Amiri RM (2008) Molecular detection of nematicidal crystalliferous Bacillus thuringiensis strains of Iran and evaluation of their toxicity on free-living and plant-parasitic nematodes. Can J Microbiol 54(10):812-822. https://doi.org/10.1139/W08-074

Sattar S, Maiti MK (2011) Molecular characterization of a novel vegetative insecticidal protein from Bacillus thuringiensis effective against sap-sucking insect pest. J Microbiol Biotechnol 21(9):937-946. https://doi.org/10.4014/ jmb. 1105.05030

Schnepf HE, Whiteley HR (1981) Cloning and expression of the Bacillus thuringiensis crystal protein gene in Escherichia coli. Proc Natl Acad Sci 78(5): 2893-2897. https://doi.org/10.1073/pnas.78.5.2893

Seshadri S, Ignacimuthu S, Vadivelu M, Lakshminarasimhan C (2007) Inorganic phosphate solubilization by two insect pathogenic Bacillus sp. In: First International Meeting on Microbial Phosphate Solubilization. Springer, pp $351-355$

Shelton AM, Zhao J-Z, Roush RT (2002) Economic, ecological, food safety, and social consequences of the deployment of Bt transgenic plants. Annu Rev Entomol 47(1):845-881. https://doi.org/10.1146/annurev.ento.47.091201.1453 09

Sick AJ, Schwab GE, Payne JM (1994) Genes encoding nematode-active toxins cloned from bacillus thuringiensis isolate PS17. Google Patents,

Singh M, Kumar P, Patel SKS, Kalia VC (2013) Production of Polyhydroxyalkanoate Co-polymer by Bacillus thuringiensis. Indian J Microbiol 53(1):77-83. https:// doi.org/10.1007/s12088-012-0294-7

Singh D, Samiksha, Thayil SM, Sohal SK, Kesavan AK (2021) Exploration of insecticidal potential of Cry protein purified from Bacillus thuringiensis VIID1. Int J Biol Macromol 174:362-369. https://doi.org/10.1016/j.jjbiomac.2021. 01.143.

Soberón M, López-Díaz JA, Bravo A (2013) Cyt toxins produced by Bacillus thuringiensis: a protein fold conserved in several pathogenic microorganisms. Peptides 41:87-93. https://doi.org/10.1016/j.peptides.2012.05.023

Vachon V, Laprade R, Schwartz J-L (2012) Current models of the mode of action of Bacillus thuringiensis insecticidal crystal proteins: a critical review. J Invertebr Pathol 111(1):1-12. https://doi.org/10.1016/j.jip.2012.05.001

Wilson MK, Abergel RJ, Raymond KN, Arceneaux JE, Byers BR (2006) Siderophores of Bacillus anthracis, Bacillus cereus, and Bacillus thuringiensis. Biochem Biophys Res Commun. 348(1):320-5.

Zakharyan RA, Agabalyan AS, Chil-Akopyan LA, Gasparyan NS, Bakunts KA, Tatevosyan PE, Afrikyan EK (1976) About the possibility of extrachromosomal DNA in creation of the entomocidal endotoxin of B. thuringiensis. Dokl Akad Nauk Arrn SSR 63:42-47

Zhang J, Li H, Tan J, Wei P, Yu S, Liu R, Gao J (2019) Transcriptome profiling analysis of the intoxication response in midgut tissue of Agrotis ipsilon larvae to Bacillus thuringiensis Vip3Aa protoxin. Pestic Biochem Physiol 160:20-29. https://doi.org/10.1016/j.pestbp.2019.06.001

\section{Publisher's Note}

Springer Nature remains neutral with regard to jurisdictional claims in published maps and institutional affiliations.

\section{Submit your manuscript to a SpringerOpen ${ }^{\circ}$ journal and benefit from:}

- Convenient online submission

- Rigorous peer review

- Open access: articles freely available online

High visibility within the field

- Retaining the copyright to your article

Submit your next manuscript at $\boldsymbol{\nabla}$ springeropen.com 